\title{
LEADER-MEMBER EXCHANGE (LMX), JOB INVOLVEMENT, AND PERFORMANCE
}

\author{
Eddy Madiono Sutanto* \\ Petra Christian University \\ Kevin Hendarto \\ Petra Christian University
}

\begin{abstract}
This study aimed to conduct leader-member exchange correlation analysis, job involvement, and performance. Data collection was done by distributing questionnaires to a number of shoe factory employees in Indonesia, especially those working in the production division. The type of research used was quantitative research with purposive sampling method. The research sample consisted of 288 employees who had worked for at least one year. The results showed that there was a positive correlation between leader-member exchange with employee performance, job involvement with employee performance, and leader-member exchange with job involvement.
\end{abstract}

Keywords: Leader-member exchange; Job involvement; Performance.

Received: 12 August 2019

Accepted: 28 May 2020

\section{INTRODUCTION}

Employees are one of the important aspects in the operation of a company. This makes employees have a big role in determining the performance of a company, so that the company's performance will be largely determined by the conditions and attitudes of each employee of the company (Sidharta \& Margaretha, 2011). To deal with these conditions, companies must have greater attention in the field of human resources, which will determine the success or failure of their use of the lucrative business growth momentum (Djawahir, 2011).

The relationship between supervisor and subordinates is one of the keys so that employee performance can be maximized. Therefore, supervisor must know how to build good relationships with subordinates, and vice versa. According to Gerstner and Day (1997), LMX is positively correlated with some desired results, including subordinate performance, job satisfaction, and organizational commitment (in O'Donnell, Yukl, \& Taber, 2012). Other research conducted by Sudirjo and Toryanto (2013) also shows the results of supervisor-subordinate relationships that have a positive correlation with employee performance. This happens because the supervisor understands how far the potential possessed by his subordinates and assigns tasks to his

\footnotetext{
*Corresponding author: Eddy Madiono Sutanto, School of Business Management, Petra Christian University, 60236, Surabaya, East Java, Indonesia. Tel: +62818391691. Email: esutanto@petra.ac.id
} 
subordinates according to their abilities. It can make subordinates who carry out these tasks will not feel burdened by the task given.

Involvement is one of the main aspects that deserves attention, especially in Indonesia. Through the results of a survey on employee job involvement in Indonesia in 2018, the engagement of employees in Indonesia shows a fairly stable increase. This is supported by the results of engagement scores which have increased from $65 \%$ to $80 \%$ over the past two years (Aon, 2018). According to Li and Long (1999) define job involvement as a degree when someone shows emotional or mental involvement with his work that has a close relationship with performance (in Khan, Jam, Akbar, Khan, \& Hijazi, 2011). In addition, according to Safira (2013) job involvement also has a relationship to employee performance. Thus, employees who have high job involvement in their jobs will have full focus on their work, so that employees will have high performance.

To ensure that employees look enthusiastic and explore the work they are doing, employers need to understand how to build good two-way relationships between supervisor and subordinates. According to Breevaart, Bakker, Demerouti, and Van den Hauvel (2015), LMX is positively related to job involvement, because high-quality supervisor-subordinate (LMX) relationships can make job involvement of subordinates also increase.

This study aims to examine the variable correlation leader-member exchange (LMX), job involvement, and performance. There is a research gap found. Previous studies never test the relationship between the three variables together. In other words, testing the previous relationship was done separately, for example between LMX and job involvement (Breevaart et al., 2015; Dewi, 2015; Dhivya \& Sripirabaa, 2015) or LMX with performance (Gerstner \& Day, 1997; Li, Liang, \& Crant, 2010; Sudirjo \& Toryanto, 2013) or between job involvement and performance (Li \& Long, 1999 dalam Khan et al., 2011; Markos \& Sridevi, 2010; Indayati, Thoyip, \& Rofiaty, 2012). The results of this study are expected to contribute positively to the development of science related to the above variables.

\section{LITERATURE REVIEW}

\subsection{Leader-Member Exchange}

According to $\mathrm{Wu}$ (2009), leader-member exchange is the quality of reciprocal relationships between leaders and each of their employees, because leaders have different quality relationships with each of their employees. The quality of relationships formed can be divided into two, namely good relationships and bad relationships. A good relationship will produce a positive attitude in employees, while a bad relationship will produce the opposite attitude. According to Liden and Masyln (1998), the leader-member exchange indicator consists of four things (in Taupan, Sunyoto, \& Kartika, 2016) that is employee contribution, employee loyalty, employee affect, and professional respect.

\subsection{Job Involvement}

Robbins (2006, p. 94) defines in a company or an organization, job involvement arises as a response to a particular job or situation in the work environment. A type of work or situation in the 
work environment will affect the person more involved or not in his work. In this case, the relationship of someone in work outside of the actual work covered (in Safira, 2013). According to Rayton and Yalabik (2014), job involvement has three indicators (in Shekari, 2015) that is employee vigor, employee dedication, and employee absorption.

\subsection{Performance}

According to Sedarmayanti (2011, p. 260), performance is a system used to assess and find out whether an employee has successfully carried out his work as a whole, or is a combination of work results (what one must achieve) and competence (how one achieves it). Retnaningsih (2007) suggests that there are four indicators used in measuring performance (in Kosasih \& Sutanto, 2014), that is the quantity of employee work, the quality of employee work, employee efficiency, and timeliness.

\subsection{Relations between Concepts}

Leader-member exchange has a correlation with employee performance. From the results of a study conducted by Li et al. (2010), Sudirjo and Toryanto (2013) state that the same results in the form of leader-member exchange (LMX) have a positive correlation with employee performance. Job involvement has a correlation with employee performance. From the results of research conducted by Markos and Sridevi (2010), Indayati et al. (2012) state the same results in the form of job involvement which has a positive correlation with employee performance. Leader-member exchange has a correlation with job involvement. From the results of research conducted by Breevaart et al. (2015), Dewi (2015), Dhivya and Sripirabaa (2015) state the same results in the form of LMX as positively related to job involvement.

$H_{l}$ : Leader-member exchange has a positive correlation with performance.

$\mathrm{H}_{2}$ : Job involvement has a positive correlation with performance.

$H_{3}$ : Leader-member exchange has a positive correlation with job involvement.

Figure 1: Research Framework

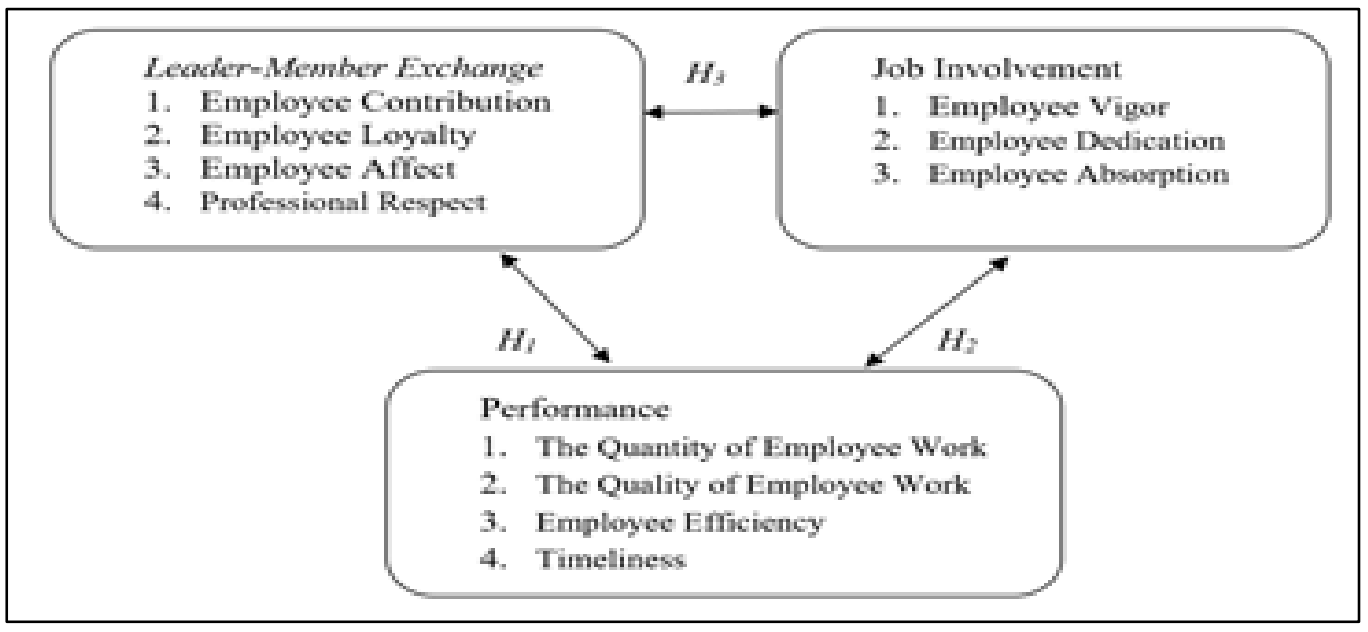




\section{RESEARCH METHODS}

The type of research used is quantitative research. The population in this study are all production employees of Shoe factory, which are 1020 people with contract status for a certain period of time, namely three years. Shoe factory is a representation of mass industries in Indonesia. The reason for the production section being investigated is because this part has an important role in the survival of a company. If there are no goods produced, then there will be no sales of goods that will bring income to the operations of a company. The technique used in sampling is purposive sampling. In addition, because of the limitations of the existing research time, the sample that will be used as a study was taken using the Slovin method with an estimated error rate of 5\%. The sample of this study was 288 employees. The results of calculating this sample are obtained by the following formula:

$n=\frac{N}{1+N \mathrm{e}^{2}}$

Remarks:

$n \quad:$ number of sample members

$N \quad$ : number of members of the population

e : tolerable sampling rates or significance levels; $e=0,05(5 \%)$

From the existing data, the number of samples in this study are:

$n=\frac{1020}{1+1020(0.05)^{2}}$

$n=288$

Data collection techniques used in this study were through questionnaires. Questionnaires were distributed directly to 288 production employees who were qualified with set criterion initially. The collection was done during working break period for several days. After checking all filled in questionnaires, collected data was classified and processed. In this study, data processing uses the SPSS for Windows version 23 program to test the feasibility of the questionnaire and find out whether there is a positive correlation between leader-member exchange with employee performance, job involvement with performance, and leader-member exchange with job involvement.

The test carried out there are three forms namely validity test, reliability test, and correlation test. Validity test is done to see whether the variable under study has a valid result or not. Valid means that the instrument can be used to measure what should be measured. Instrument reliability test is a requirement for testing validity. Therefore, although valid instruments generally must be reliable, testing of instrument reliability needs to be done (Sugiyono, 2017, p. 121). According to Sunyoto (2016, p. 57), the correlation test is to test whether two variables, namely the independent variable and the dependent variable have a strong or not strong relationship, whether the relationship is positive or negative. 


\section{DATA ANALYSIS}

There were 288 people who were respondents to this study. The majority of respondents had female sex with a total of 277 people $(96.2 \%)$. This is because to carry out production activities requires only a little energy and greater patience. In terms of age, the majority of respondents were 31-40 years old $(46.5 \%)$. These results indicate that if the majority of respondents were employees of 31-40 years old. There were 82 people. This is because employees in the age range of 31-40 years already have sufficient work experience and that age range can be classified in the age range that is considered productive for a worker. In terms of recent education, the majority of respondents were graduates of the junior high school education level of 113 people $(39.2 \%)$. This is because the work of these parts is classified as easy and can be done by employees with various educational backgrounds. In terms of working time, the majority of respondents have worked for more than four years, amounting to 153 people (53.1\%). These results indicate that employees who work have a high level of loyalty because the number of employees who work for more than four years is far more than employees who have a working period of one to two years and three to four years.

\subsection{Validity and Reliability Test}

According to Sugiyono (2017, p. 121), the results of the study can be said to be valid if there are similarities between the data collected and the data that actually occurs in the object under study. The technique used to test the validity is the product moment Pearson correlation. All statement items of the research instruments show if the leader-member exchange, job involvement, and employee performance variables have a significance value smaller than 0.05 and $r_{\text {count }}>r_{\text {table }} 0.113$, so that statement items measuring research variables declared to be valid. On the other hand, all leader-member exchange variables, job involvement, and employee performance can be stated reliably. This is evident from the Cronbach alpha results greater than the critical value of 0.60.

\subsection{Cross Tabulation Analysis}

In order to explore how the relationship between variables, therefore this research have done cross tabulation analysis, which are between respondent's profile with latent variables (leader-member exchange, job involvement, and job performance) as explained next consecutively.

Relate to leader-member exchange, the results indicate some interesting findings. In term of gender, employees with female gender feel more about the quality of a good working relationship between themselves and their supervisors than employees with male gender. This is because women are more patient and more be able to find ways to build good working relationships with their supervisors. In term of age, employees aged 31-40 years feel more about the quality of a good working relationship between themselves and their supervisors. This is because at the age of 31-40 years, employees are more productive and have considerable experience so supervisors are more comfortable in establishing working relationships with them. In term of education background, employyees who have a background in high school education feel more about the quality of a well-working relationship between themselves and their supervisors. This is because employees who have the last high school education have broader theoretical knowledge than employees with other recent education such as elementary, junior high, and vocational schools. So supervisors are more likely to discuss with them. In term of the length of work, the longer the working period of a worker shows the better quality of work relations between himself and their 
supervisor. This is because in the working period that has reached over four years, employees and supervisors should know each other's personalities and traits for a long time.

Relate to job involvement, the results indicate some interesting findings. In term of gender that both male and female employees still have a low desire for job involvement. This is due to the lack of desire and intrinsic encouragement that employees have to be willing to be involved in every work done. In term of age, employees aged 31-40 years are less willing to be involved in the work they do. This is because at the age of 31-40 years, employees tend to only want to do the work done every day without any desire to try to do something new. In term of education background, employees who have a junior and senior high school education background agree more if they are involved in the work done. This is due to the practical experience possessed by employees with middle school and high school education background whose intensity (number) is less than that of employees with a vocational education background. In term of the length of work, employees who have worked more than four years are more willing if they are involved in the work done. This is because employees who have worked for more than four years are comfortable with the working conditions they feel every day and they also know the amount of compensation received if they are willing to be involved more deeply in the work done.

Relate to job performance, the results indicate some interesting findings. In term of gender that both male and female employees are willing to give the best performance. This is because the nature of the employee should work because if the employee does not show good results, they will get a warning from their supervisor. In term of age, employees aged 31-40 years are more willing to give the best performance. This happens because employees who are 31-40 years old still have great enthusiasm and desire to work to reach a high career path in a certain position. In term of education background, employees from various educational backgrounds agree to give the best performance. This happens because it is an obligation that must be shown by every employee who works in a company. In term of the length of work, employees who have worked more than four years are available to provide the best performance. This is because employees who have worked for more than four years are familiar with their work routines, so that these employees will not experience problems if they have to provide the best ability they have.

\subsection{Correlation Relationship Analysis}

In order to answer the research questions and the hypothesis test, correlation relationship between variables are tested and the results are showed in Table 1, 2, and 3.

Table 1: Correlation Test Results between Leader-Member Exchange and Performance

\begin{tabular}{lcc}
\hline \hline & & Performance \\
\hline Leader-Member Exchange & Correlation Coefficient & 0.008 \\
& Sig.(1-tailed) & 0.446 \\
& $N$ & 288 \\
\hline \hline
\end{tabular}

Table 1 shows that there is a positive correlation between leader-member exchange and employee performance. From the results of calculations using the existing formula, the correlation coefficient value of 0.008 is categorized as positive and the correlation is very low. 
Table 2 shows that there is a positive correlation between job involvement and employee performance. From the results of calculations using the existing formula, the correlation coefficient value is 0.196 which is categorized as positive and the correlation is very low.

Table 2: Correlation Test Results between Job Involvement and Performance

\begin{tabular}{lcc}
\hline \hline & & Performance \\
\hline Job Involvement & Correlation Coefficient & 0.196 \\
& Sig.(1-tailed) & 0.000 \\
$N$ & 288 \\
\hline \hline
\end{tabular}

Table 3: Correlation Test Results between Leader-Member Exchange and Job Involvement

\begin{tabular}{lcc}
\hline \hline & & Job Involvement \\
\hline Leader-Member Exchange & Correlation Coefficient & 0.005 \\
& Sig.(1-tailed) & 0.467 \\
& $N$ & 288 \\
\hline \hline
\end{tabular}

Table 3 shows that there is a positive correlation between leader-member exchange and job involvement. From the results of calculations using the existing formula, the correlation coefficient value of 0.005 is categorized as positive and the correlation is very low.

\section{DISCUSSION}

Table 1 shows correlation test results can be decided including the category of positive or negative seen from the correlation coefficient value generated, while to find out whether the results are significant or not seen from the significance value (1-tailed). If the significance value (1-tailed) is more than 0.05 then it can be said to be insignificant, and vice versa if the significance value (1tailed) is less than 0.05 then it can be said to be significant. The results of this study are supported by research conducted by Li et al. (2010); Sudirjo and Toryanto (2013) show that the same results in the form of leader-member exchange (LMX) have a positive correlation with employee performance. From the results of the analysis of existing data shows there is a positive correlation that occurs but insignificant between leader-member exchange with employee performance. This means that production division employees who have good or bad performance do not entirely depend on the quality of work relationships that are well established between superiors and subordinates. For example, employees who are able to work carefully and are able to produce good jobs do not entirely depend on the quality of the work relationship good between themselves and their supervisor. Therefore, the way that can be done so that the employee can perform well then there must be a sense of responsibility and intrinsic encouragement in each of the employees.

Table 2 shows correlation test results can be decided including the category of positive or negative seen from the correlation coefficient value generated, while to find out whether the results are significant or not seen from the significance value (1-tailed). If the significance value (1-tailed) is more than 0.05 then it can be said to be insignificant, and vice versa if the significance value (1tailed) is less than 0.05 then it can be said to be significant. The results of this study are supported 
by research conducted by Markos and Sridevi (2010) and Indayati et al. (2012) shows the same results in the form of job involvement which has a positive correlation with employee performance. From the results of the analysis of existing data indicate there is a positive and significant correlation between job involvement with employee performance. This means that production division employees who are able to work carefully can be caused by having high concentration and employees who always arrive on time at work can be caused by having a genuine willingness to work.

Table 3 shows correlation test results can be decided including the positive or negative category seen from the correlation coefficient value generated, while to find out whether the results are significant or not seen from the significance value (1-tailed). If the significance value (1-tailed) is more than 0.05 then it can be said to be insignificant, and vice versa if the significance value (1tailed) is less than 0.05 then it can be said to be significant. The results of this study are supported by research conducted by Breevaart et al. (2015), Dewi (2015), Dhivya and Sripirabaa (2015). It showed the same results in the form of LMX positively related to job involvement, because good quality leader-member exchange (LMX) can make job involvement of subordinates also increase. From the results of the analysis of existing data indicate there is a positive correlation that occurs but not significant between leader-member exchange with job involvement. This means that production division employees who have high or low job involvement do not fully depend on the quality of the work relationship that exists between supervisors and subordinates. For example, employees who are able to work with high concentration in their work do not fully depend on the quality of the work relationship good between themselves and their supervisor.

Table 4: $F$ Test Results

\begin{tabular}{cccc}
\hline \hline Model & $\boldsymbol{F}_{\text {table }}$ & $\boldsymbol{F}_{\text {count }}$ & Sig. \\
\hline Regression & 3.04 & 6.451 & 0.002 \\
\hline \hline
\end{tabular}

From the results of processing as shown on Table $4, F_{\text {count }}$ of 6.451 shows a value greater than the value of $F_{\text {table }}$ of 3.04 and a significance value below 0.05 , so it can be stated that the results of the correlation model that has been produced are feasible to use.

\section{CONCLUSION AND IMPLICATION}

From the analysis and discussion that has been done, it can be concluded that the leader-member exchange has a positive correlation with employee performance, job involvement has a positive correlation with employee performance, and leader-member exchange has a positive correlation with employee job involvement. From the conclusions and results of the existing research, the advice that will be given in this study is that the production supervisor is suggested to be able to create conducive and comfortable working conditions for the workers, so that employees are willing to establish good cooperative relationships with supervisors. The management, especially the production supervisor, must make the production employees feel proud of their work, so that from that feeling of pride will arise the desire of employees to participate actively involved in activities or solving problems related to the production process. In addition, it is also recommended that you establish a reward system for employees who are able to exceed the target number of production set. 
Further research is expected to be able to connect variables other than those that have been studied above on employee performance to find out variables that have a dominant positive relationship on employee performance in a company.

\section{REFERENCES}

Aon. (2018). Trends in global employee engagement. Retrieved from http://www.aon.com/attachments/human-capital-consulting/2018-trends-in-global-employee-engagement-report.pdf

Breevaart, K., Bakker, A. B., Demerouti, E., \& Van den Hauvel, M. (2015). Leader-member exchange, work engagement, and job performance. Journal of Managerial Psychology, 30(7), 754-770. doi: 10.1108/JMP-03-2013-0088

Dewi, E. P. (2015). Hubungan antara dimensi lmx dengan employee engagement pada karyawan Sumber Baru KIA Yogyakarta (Unpublished undergraduate thesis). Universitas Sanata Dharma, Yogyakarta, Indonesia.

Dhivya, A. S., \& Sripirabaa, B. (2015). The impact of leader member exchange on work engagement: An empirical study. International Journal of Management, 6(1), 139-150.

Djawahir, K. (2011, January). Optimisme memuncak di tahun kelinci emas. Retrieved from https:// swa.co.id/sajian-utama/optimisme-memuncak-di-tahun-kelinci-emas

Gerstner, C. R. \& Day, D. V. (1997). Meta-analytic review of leader-member exchange theory: Correlates and construct issues. Journal of Applied Psychology, 82(6), 827-844.

Indayati, N., Thoyip, A., \& Rofiaty. (2012). Pengaruh keterlibatan karyawan, budaya organisasi, dan gaya kepemimpinan terhadap komitmen organisasional dalam meningkatkan kinerja karyawan (Studi pada Universitas Brawijaya). Jurnal Aplikasi Manajemen, 10(2), 344356.

Khan, T. I., Jam, F. A., Akbar, A., Khan, M. B., \& Hijazi, S. T. (2011). Job involvement as predictor of employee commitment: Evidence from Pakistan. International Journal of Business and Management, 6(4), 252-262.

Kosasih, Y. S., \& Sutanto, E. M. (2014). Pengaruh budaya dan komitmen organisasional terhadap kinerja karyawan. Jurnal Agora, 2(1), 665-673.

Li, N., Liang, J., \& Crant, J. M. (2010). The role of proactive personality in job satisfaction and organizational citizenship behavior: A relational perspective. Journal of Applied Psychology, 95(2), 395-404.

Markos, S., \& Sridevi, M. S. (2010). Employee engagement: The key to improving performance. International Journal of Business and Management, 5(12), 89-96.

O’Donnell, M., Yukl, G., \& Taber, T. (2012). Leader behavior and lmx: A constructive replication. Journal of Managerial Psychology, 27(2), 143-154.

Safira, S. (2013). Pengaruh keterlibatan kerja terhadap kinerja pegawai pada PT Seascape Surveys Indonesia. E-Jurnal Manajemen dan Bisnis, 1(1), 1-17.

Sedarmayanti. (2011). Manajemen sumber daya manusia, reformasi birokrasi manajemen pegawai negeri sipil. Bandung: Rafika Aditama.

Shekari, H. (2015). Evaluating the three dimensions of work engagement in social security organization of yazd province in Iran. Journal of Education and Management Studies, 5(3), 168-174. 
Sidharta, N., \& Margaretha, M. (2011). Dampak komitmen organisasi dan kepuasan kerja terhadap turnover intention: Studi empiris pada karyawan bagian operator di salah satu perusahaan garment di Cimahi. Jurnal Manajemen, 10(2), 129-142.

Sudirjo, F., \& Toryanto, A. A. (2013). Pemberdayaan kerja profesional sebagai mediasi dukungan organisasi dan pertukaran pemimpin-anggota $(\operatorname{lmx})$ terhadap komitmen organisasional. Jurnal Ekonomi, 2(2), 134-151.

Sugiyono. (2017). Metode penelitian kuantitatif, kualitatif, dan $r \& d$ (25 th ed.). Bandung: Alfabeta.

Sunyoto, D. (2016). Teori, kuesioner, dan proses analisis data perilaku organisasional. Yogyakarta: CAPS (Center for Academic Publishing Service).

Taupan, F., Sunyoto, C., \& Kartika, E. W. (2016). Hubungan leader-member exchange dan komitmen organisasional: Studi pada karyawan restoran D'cost Seafood Surabaya. Jurnal Hospitality dan Manajemen Jasa, 4(2), 134-146.

Wu, Y. J. (2009). A multidimensional analysis of the relationship between leader-member exchange and organizational citizenship behavior with an alternative measure of leadermember exchange (Dissertation). School of Business Organizational Studies Program, New York, USA. 